\author{
Daiva Jakavonytè-Staškuviene \\ Lithuanian University of Educational Sciences \\ daiva.jakavonyte@gmail.com
}

\title{
The policy of integrated languages didactics in Lithuania
}

\section{Summary}

The article analyses the policy, theory and research-based practice of integrated languages didactics. It discusses teaching quality, determining factors, the role of integrated languages didactics, its challenges and sensitive aspects in organising integral learning. The development of learning curriculum (depending on the context) and reflection activities are the key element in establishing quality-focused integrated learning practices.

Keywords: integrated languages didactics, learning policy

\section{The relevance of the problem}

In today's globalised world as a result of people moving around and changing the place of residence children frequently find themselves in a situation where they study in a language that is not their native. For example lately this has been the case in Lithuania, as there are more and more families with parents of different nationalities and languages, where they speak English between them. Some of Lithuanian citizens return home after having lived abroad and their children go to schools with Lithuanian as the main language although a lot of them speak English better than Lithuanian and have poor Lithuanian reading and writing skills. Language learning and skills are the basis for personal communication, socialising and developing other skills. Lithuanian due to its complex structure is a language quite difficult to learn, therefore there is great political focus on integrated language learning through other subjects. Integrated development of language skills especially in the domains of reading and writing is believed to ensure better student performance not only in language learning but also in other subjects. As over the last decade Lithuanian student progress in language learning has been on a steady decrease (according to findings of PIRLS 2006, 2011; PISA 2012), there is a large concern about the improvement of student performance. All before mentioned international studies show that the number of students with a superior literacy in maths and natural sciences, especially in reading skills, is low. The learning process is in need of customisation, differentiation, a wider range of assignments with different grades of difficulty, more focus on developing the skills of bright students that seek the highest results. Lithuania needs to find new ways to improve student motivation and their wish to learn, to build their confidence especially when it comes to girls. Improved progress has been listed as one of the objectives in the Lithuanian National Education Strategy for 2013-2022 (2013), where the key goals include the following: to bring pedagogical communities to such a level 
that the majority of their members would be reflective, continuously developing, efficient professional teachers and instructors; to implement educational culture based on data analysis and self-assessment. Improving teacher motivation is also an important factor as teachers highly influence the progress of students. However, the Recommendation by the European Council (2016: 4) states that even if educational progress in on the rise, a lot of students lack sufficient basic skills. The focus should be on high quality teaching which is key in solving problems of low learning progress and gaps in the education system. Therefore it can be said that Lithuania understands the need of efficient education and improving student performance but fails to find ways to create such a school that each and every student would and could achieve certain results. Integrated learning is believed to be one of the possible solutions. However, at the moment the Lithuanian teaching community lacks knowledge and skills for its efficient execution.

The aim of the research is to analyse the research-based policy and practice of integrated language didactics.

Objective of the research is defining theoretical assumptions enabling efficient organisation of integrated languages didactics.

\section{Research methodology}

The qualitative research is based on the strategy of qualitative content analysis. The research design is based on the methodological framework by qualitative research theoreticians Bitinas, Rupšiene, Žydžiūnaitè (2008). It is a theoretical research conducted in accordance with methodological research stages: reading and analysing theoretical research material and summarising subject-specific (integrated languages didactics) references. The choice of synthetical analysis allows joining different information sources into a meaningful contextual basis and inter-connecting individual research, studies, interpretations and conclusions on the same subject of integrated languages didactics. The method of data analysis is based on the insight approach and its process is interpretational based on the expertise, experience and intuition of the research author. The main strategy for data analysis is drawing comparisons: it consists of comparing significant research indices in integrated language didactics, i.e. views of other researchers on the subject. They are later linked to the research problem offering an attempt to understand and identify relations between different (often alternative) research indices. The theoretical research was carried out in May-June, 2015 during the author's academical visit at Paul Valéry University, Montpellier III in France.

\section{Key concepts of integrated languages didactics}

(Coste 2002; Adams 2006; Chomentowski 2009; Maurer 2014)

Integrated languages didactics is understood as a multilingual competence defined as the basis of knowledge and skills which a person can use under certain circumstances, in certain situations and certain contexts. This definition describes the situation of children of 
migrant families. They have the capacity to speak a number of languages in different life situations (the one required in each case) and a wide range of cultural experiences. Nevertheless, these children can face educational failure in the environment of an unknown language and culture. Multilingual competences have a dynamic nature. The concept of multilingual competences may be the road to intercultural, multicultural education. Before setting up a teaching plan the teacher should take into consideration languages spoken by his or her students. Moreover, researchers point out the necessity to be aware that the official language at school might not be the language spoken by the student outside. Another challenge is a poorly developed written language which remains at the colloquial level. This problem is often referred to as a poor vocabulary, inability to fluently express thoughts in writing. The richness, subjectivity and aesthetics of the written language are rare among students. Even university teachers complain about insufficient student lexicon, a limited number of expressions and rare use of figures of speech. School should always be a reminder of the fundamentality of culture. And in reality this fundamentality cannot be delivered without the help of media. Writing has so far been limited to putting spoken thoughts in characters (symbols) but at school this should be taken to a higher level. Language is a way to learn about the world. For this to happen the written form has to have a result (enduring value). Cultural knowledge is increased through project activities. Migrants should try to integrate not only socially but also culturally. Learning a foreign language should include intercultural and metacultural domains. After all, children are brought not only to a new country, they are introduced to a new culture which they must learn about. Insufficient access to learning and cultural knowledge leads to a failed integration into society through education. Chomentowski (2009) argues that sociolinguistic dimension plays an important role in terms of education as it has become an integral part of a prevailing new approach to this problem. The author agrees that teaching should be concerned with every student's individual situation: subject specific competences, psychological condition (willingness to learn), culture, identity.

When it comes to integrated languages didactics the school should agree on the principles, directions and frequency of integrated learning. If the focus is on integrated language learning it is foremost necessary to consider the language structure; if other subjects are in question it is recommendable to identify a set of competences that will be integrated. Quality is a result of motivation, teacher cooperation, curriculum planning, integrated approach. Another important factors are educational environment, benevolence, defining common goals and pursuing them (by CARAP 2007; Candelier 2008; Mazunya and Djihouessi 2014). Before adopting the integrated didactics approach it is necessary to assess human and material didactic resources and their quality. The focus should be place not only on the linguistic but also on the cultural context which affects learning curriculum and learners. For example, if we are studying two languages we refer to a multilingual situation and a multilingual and multicultural environment covering cultural diversity, the knowledge of it, understanding its similarities and differences. Teachers should be aware of the culture students come from, be tolerant of cultural differences, find out the values of 
students, which provide support in the learning process. This knowledge is a key element in implementing integrated didactics processes.

\section{Factors to be taken into account in developing integrated didactics}

The most important parameter in integrated didactics is teaching quality. Learning two subjects at the same time independently on the nature of the subjects (two languages or language and mathematics, language and history) is a challenge in itself as it is necessary to know precisely the purpose and the method so that both subjects can be learned efficiently. The choice presents a challenge as it requires to think about language learning and academic knowledge of the other subject; assess competences of both students and teachers, their determination to apply this approach, from a different perspective than before (on the basis of non-integrated learning). The next step after reflecting on the experience is to plan the procedure further: discuss integrated assignments and activities. Another aspect is the learning curriculum implemented taking into account all the fundamental elements: from planning an assignment to assessing the results. The curriculum depends on the following integral, inter-related and inter-dependent structural components:

- Knowing your students and their capacities of the two subjects that will be included in integrated didactics.

- Knowledge of communication models and the ability to organize teaching process to integrate linguistic training in an efficient way.

- Developing teaching processes based on the particular class situation and teacher competence.

- Developing intercultural pedagogy.

- Mobilising quality ensuring resources (human, material, financial resources, training accesses).

- Setting up particular models (following the analysis of documents, research-based instruments, best practices).

- Improving and upgrading teacher competences in the targeted domain of integrated didactics through collaboration.

Carrying out a thorough analysis of best practices and determining teacher's experience and how closely it is linked with best practices. In other words, it is advisable to invest more time into preparation rather than feel frustrated as a result of lacking experience in the field.

\section{Contextualisation of student knowledge construction}

(Bretegnier, Etienne, Adami 2011; Douillard, Vinérier, Carré 2011)

There is always an open question regarding the learning of the second, third or any other language: whether it will be done considering the student's personality and individual skills or focusing on the language specifics and disregarding the student's individuality. 
Language learning is always associated with self-expression, identification of thought in the context of that particular language (Prudent 1981). Self-identification is greatly restricted if the language is perceived as illegitimate or impossible to grasp or master. A lot depends on the student's attitude as well. Vinérier (2007) notes that feelings and learning difficulties are often reflected in student's stories of school failure and negative experience. The failure to analyse and solve these problems can lead to student isolation and locking their knowledge at a certain level, negative thinking and refusal to learn. These problems and situations are common in all age groups.

Depending on the situation, context teaching should be organised under the principle: knowing - knowing/doing - knowing/being (by Douillard, Vinérier, Carré 2011; Maurer 2014). These are elements comprised within teacher's competence. Students must be provided with material on language differences, how to be aware of them and learn to co-exist, i.e. prepare students to live in the society with linguistic and cultural differences. Agnès (2013), Shankland (2013) and Tarpinian (2013) believe that with a great deal of life in the modern world being virtual it is very important to develop the skills to learn to know (to know), to learn to do (to act), to learn to live together. All of which require knowing the language, the ability to explain things in such a clear way that it would be understandable without seeing your interlocutor; perform assignments in a timely and efficient manner. This is why it is essential to be culturally aware, know who you can work and interact with at the other end of the virtual line. It is up to school not only to explain these instruments but also teach how to operate them.

Let us have a better look at what the key words in Table 1 refer to in integrated didactics.

Table 1. Integrated languages didactics under the principle of knowing, knowing-doing, knowingbeing (by Douillard, Vinérier, Carré 2011)

\begin{tabular}{|c|c|c|}
\hline Knowing & Knowing-doing & Knowing-being \\
\hline $\begin{array}{l}\text { - Knowing (linguistic and } \\
\text { other subject) your students; } \\
\text { - Institutional context and } \\
\text { global agreements; } \\
\text { - Pedagogy (how will be } \\
\text { integrated language and } \\
\text { content of the topic). }\end{array}$ & $\begin{array}{l}\text { - Support and positive } \\
\text { attitude (upgraded } \\
\text { curriculum); } \\
\text { - Methodology (learning } \\
\text { language and study } \\
\text { integrally); } \\
\text { - Organisation of learning } \\
\text { (learning language and } \\
\text { study integrally). }\end{array}$ & $\begin{array}{l}\text { - } \text { Reflection on practice; } \\
\text { - } \text { Reflection on pedagogical } \\
\text { relationship (learning } \\
\text { language and study } \\
\text { integrally); } \\
\text { - Reflection on peer } \\
\text { relationship (learning } \\
\text { language and study } \\
\text { integrally). }\end{array}$ \\
\hline
\end{tabular}

\section{Knowing}

Knowing your students refers to the teacher's awareness of any challenging situations in public media faced by students due to insufficient knowledge of a language; learning about their situation in social environment, family and school; analysing learning difficulties in different areas and subjects; reflecting on providing help; analysing needs and reasons behind the motivation to study languages or any other subject. 
Institutional context and global agreements refer to enabling students to know the historical context of learning and its development; learning about didactics (the foundation upon which knowledge is constructed); knowing different types of teaching institutions and possible partners to cooperate.

Pedagogy refers to learning about trends in teaching students and being able to choose the best ones; knowing the students, finding out their learning difficulties, areas for improvement in terms of linguistic (oral communication, reading, writing) and cognitive aspect (motivation, space, time, actual experience, knowledge...); knowing different theoretical ideas upon which the choice of particular methods and instruments is based; knowing students' key target competences.

\section{Knowing/doing}

Support and a positive attitude (upgraded curriculum) refer to adopting attitudes that encourage positive and supportive thinking (each and every situation has an explanation); developing school projects together with students (there is a wide range of integrated activity projects: integrated subject-related projects, social and cultural projects, family projects...); explaining project development and implementation: its place and the role and assignment of every project member; reflecting on target competences (prior to the activity reflecting on student's actual knowledge and abilities, target skills as well as on the improvement in student's field of knowledge).

Methodology refers to the development of student-oriented curriculum; in view of the situational context, goals and expected results, choosing appropriate instructing strategies; knowing how to apply available teaching instruments; preparing assessment criteria that would encourage self-assessment; preparing an activity reflection questionnaire, criteria, result recording, etc.

Organisation of learning refers to the ability to control the class, organise activities in groups (knowing how to split students into groups according to target goals such as achievements, abilities, activity content, etc.) and learning with peers; knowing and successfully applying encouragement and motivational techniques to ensure the willingness to learn and think positively; being able to solve problems.

\section{Knowing/being}

Reflection on practice refers to analysing teaching activities by comparing the process with the result; re-evaluating strategies, methods; and all of this via consultations and practice exchange with colleagues.

Reflection on pedagogical relationship refers to the development of positive thinking which would encourage students to learn (empathy, comprehension, unconditional positive approach...); focusing on the person taking into consideration his or her culture; encouraging collaboration; reviewing your own image, role, representation inside and outside the institution. 
Reflection on peer relationship refers to fostering the culture of friendly collaboration; searching for best solutions and answers in the context of each situation; always trying to work and deliver with the highest possible efficiency given that particular situation.

The key to a high-quality integrated education is its participants' ability to reflect (on the process and the result). This can only be achieved through the development of meta-cognitive skills that help optimise and improve the quality of education and student progress (by Brown, Palinscar 1982; Borkowski et al. 1990; Paris, Winograd 1990; Coste, Moore, Zarate 2009; Sagnier 2013; Stalder 2010, 2013; Gohard-Radenkovic, JakavonytèStaškuvienė, Skakova 2015). Swiss researchers (Stalder 2010, 2013; Gohard-Radenkovic 2015) identify strong reflective skills as the key competence in a teacher. Constant reflection before, during and after the activity preconditions efficient results. Teacher's ability to apply the right learning strategies; help a student or a group of students in a timely manner and at the right pace enable success. All of this is impossible to achieve without socio-cognitive and meta-cognitive skills; certain epistemological approaches; a detailed context and a thorough cultural knowledge. If this foundation is removed education becomes fragmented and usually fails to achieve the required or desired result. No problem can be solved without good reflective skills. In order to enable debates and discussions on any subject we should be able to point out the strengths in the field and the weaknesses that must be improved to change the situation. Social cognition-based tasks pioneered by Vygotsky (1978) are still present and applied in the context of European education. Curriculum planning and development is an interdisciplinary field which covers an enormous amount of inter-related areas and everything starts with the knowledge of the social context and situation assessment. Every study subject should be based on a number of interdisciplinary areas such as anthropology, sociology, education psychology, social psychology and teaching sciences: pedagogy and didactics. A didactic approach is an integrated approach that helps identify theoretical elements and concepts which prevail in these different fields; and answer certain curriculum quality related questions. Education didactics should propose actions and solutions including methodology, programms, goals and specific curriculum in organising teaching/learning process in any field. The pedagogical dimension should provide solutions related to curriculum planning, implementation and reflection. In my opinion, the Lithuanian research in this field is quite scattered and there is a pedagogical failure to integrate subjects, adopt a detailed and integrated approach to every problematic area joining all the possible experience. The ultimate goal of an advanced educator is a daily teaching practice supported by a reflective approach based on theoretical grounds and providing a range of methodical-strategical learning options for students. The entire reflection on learning should be based on three key concepts: integrated subject curriculum, teaching design and learning design. The choice of design models depends on a number of factors which in turn determine the choice of pedagogical approaches and actions as shown in Figure 1: 


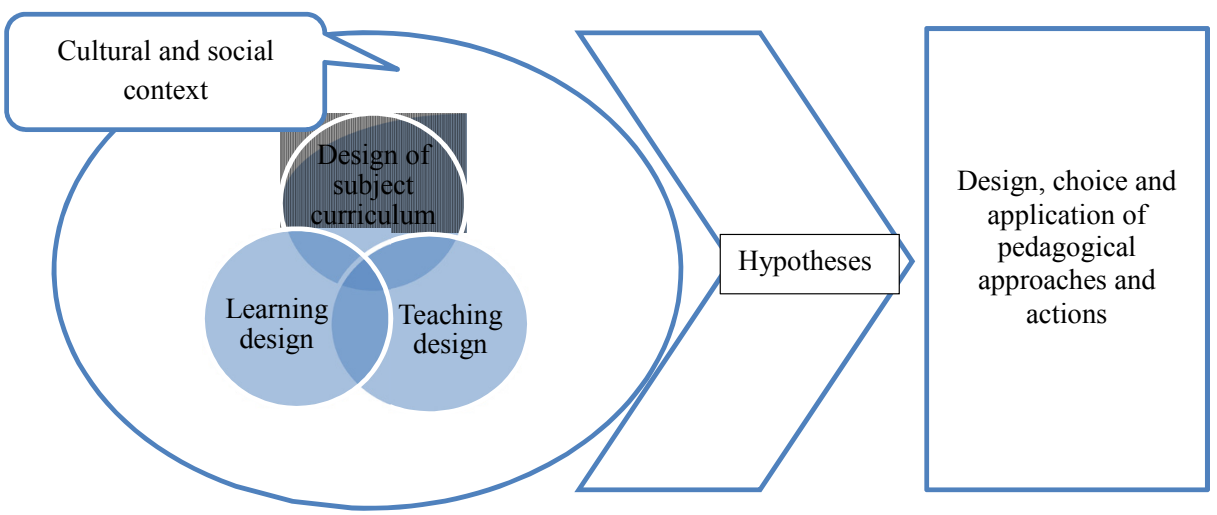

Fig 1. Integrated didactics concepts (by Sagnier 2013)

The multi-faceted analysis of a teaching situation (or learning situation) requires taking into consideration a number of inter-related factors such as human, subject-related, contextual and situational within consistent dynamics.

Activity reflection as the foundation of integrated languages didactics. Briefly consider the progress of every student. Then on the basis of your notes and personal experience/memories critically analyse their progress determining strengths and weaknesses. This activity allows an adequate overview of the current situation in class and establishing similarities and differences between the students which will help in designing subject curriculum and support measures that will allow students to strive for better education quality. At this point I dare say that we have very well mastered some aspects of the field (for example, planning, foreseeing the results), however we still lack efforts and time for a deeper analysis of the activity. The second table contains the education process can be, how to organise pupils, to reflect on the workings of the pupils' work.

Table 2. Questions to reflect on integrated education activities (has been created by the author)

\begin{tabular}{|l|l|}
\hline Questionnaire of performance analysis: & \\
\hline What model of integrated curriculum did you apply? & \\
\hline What linguistic and business skills have been educated? & \\
\hline What was your role (how did you teach)? & \\
\hline What was the progress of the students, what were signs of their success? & \\
\hline What techniques did you employ to give them feedback? & \\
\hline What were main student activities? & \\
\hline Methodological/learning strengths and points for improvement (problem identification) \\
\hline Advantages and positive moments & \\
\hline Points for improvement and negative moments & \\
\hline Summary and general remarks & \\
\hline
\end{tabular}


Reflection allows reviewing every person's knowledge, performance and strategies focusing on the procedural domain: planning, control and adjustment of cognitive processes. There exists a key relationship between metacognition and learning management (by Paris, Winograd 1990). Metacognitive abilities allow analysing didactic instruments applied in the learning process including cognitive, emotional and social aspects. Key concepts for learning models are the following: assignments, learning strategies, metacognition and process regulation, including the respective roles of teacher and students. The metacognitive model starts at knowing your students, finding out their knowledge in certain fields. Only this way learning can be conscientious and encourage the development of cognitive and metacognitive strategies and modeling, and consolidate them in educational practice through engaging activities. The scope of assignments should be wide and significant and include Vygotsky's (1978) zone of proximal development where children engage in activities which are neither too hard nor too easy but must be performed with an effort. I must admit this is still sometimes a challenge in Lithuania as more complicated assignments are rejected in fear of them being too complicated and children struggling too hard. Another frequent case is the failure to determine child's existing knowledge and his progress prior to school.

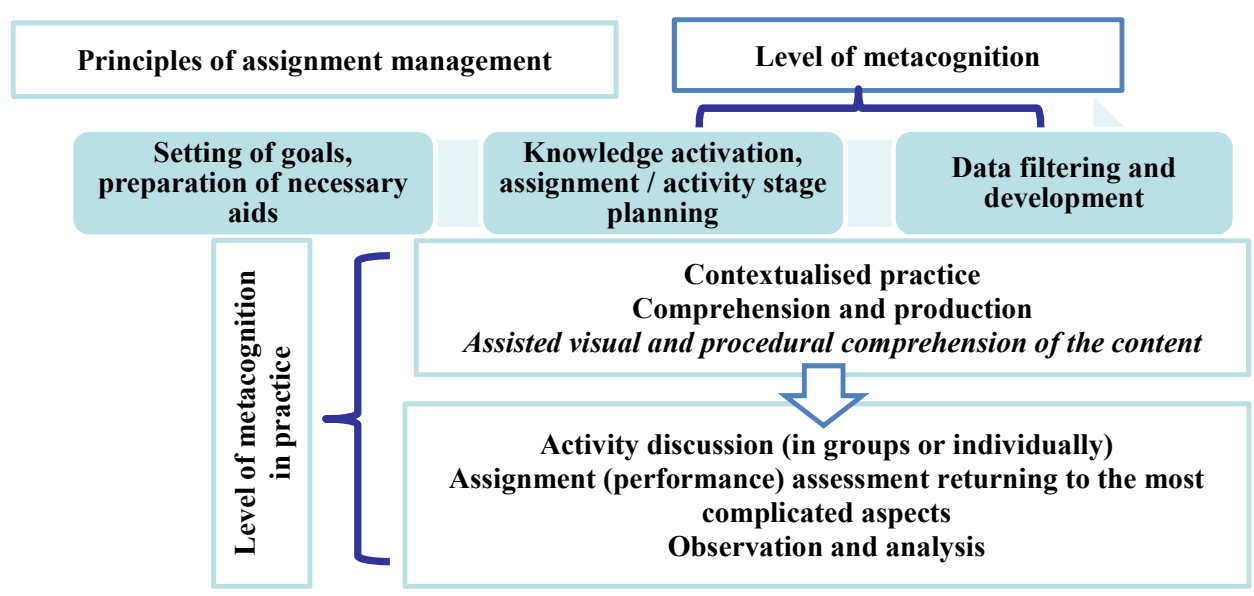

Fig. 2. Assignment management chart (by Sagnier, 2010)

Figure 2 shows the great number of elements involved in assignment management, therefore assuring its quality is a complicated task because learning activities are developed upon observation and examination of the learning situation, contextualisation of practice (enabling visual and procedural understanding of the content) and analysis of all stages (from the plan to the result). It is the agreement of all these elements and an integrated approach that determine the quality of education. 


\section{Conclusions}

1. Prior to planning an integrated education model it is necessary to assess the learning situation and determine criteria for quality, i.e. assess the starting point. Then, after all specialists of the subjects to be integrated have discussed it and come to an agreement we can move towards integration in small and well-considered steps. Efficient integrated activities and/or assignments should only be developed after a thorough assessment of student ability and teacher experience in all areas of integrated curriculum and after choosing appropriate didactic aids and methods. There has been little research carried out in the field in Lithuania therefore it is necessary to make larger investments into educational practice and context analysis at the national level. Then we can expect high-quality education and better student progress.

2. In order to achieve a high-quality integrated education teachers and students must have metacognitive abilities. The relationship between metacognition and learning ability management is crucial. Metacognitive abilities allow reflecting on didactic instruments applied during the learning process including cognitive, emotional and social aspects. Reflection is based on cognitivity which includes science-based knowledge and procedural command, i.e. analysis, synthesis, problem solving; reflection on the strategies that have been chosen and applied).

3. This article could serve as a recommendation for education policy and practice with the goal to efficiently organise education practice converging with integrated languages didactics, as the theoretical study of the article summarises researcher insights on the design and development of integrated didactics. The article discusses the advantages, complexities and challenges of integrated curriculum.

\section{References}

Adams A. (2006), Éducation: from conception to graduation. À Systemic, Integral approach. These de doctorat $(\mathrm{PhD})$ en philosophie dirigée par le professeur Alfonso Montouri, CIIS, California Institute of Integral Studies, San Francisco, CA, USA. Also available at: $<$ http://www.wisdompage.com/AnneAdamsDissertation.pdf $>$ Accessed 10.08.2016.

Agnès J. (2013), Éducation et nouvelles donnes. À propos du «changement de paradigme». / dans J.-D. Rohart. Renouveler l'éducation. Ressources pour des enjeux anthropologiques nouveaux. France, La Chronique Sociale.

Bitinas B., Rupšienė L., Žydžiūnaitė V. (2008), Kokybiniu tyrimu metodologija, I-II d. Klaipėda, S. Jokužio leidykla-spaustuvè.

Borkowski J.G., Carr M., Rellinger E., Pressley M. (1990), Self-regulated cognition: interdependence of metacognition, attributions, and self-esteem. In: J.B. Fly, I. Lorna (Eds.), Dimensions of Thinking and Cognitive Instructions. Hillsdale. NJ, Lawrence Erlbaum Associates, Inc.

Bretegnier A., Etienne S., Adami H. (2011), Définir le champ de la formation linguistique en contextes d'insertion. In: A. Bretegnier (dir.), Formation linguistique en contextes d'insertion. 
Compétences professionnelles, posture, professionnalité: concevoir un cadre de référence(s), Collection «Transversales», 28. Bern, Peter Lang.

Brown A.L., Palinscar A.S. (1982), Inducing strategic learning from texts by means of informed, self-control training. "Topics in Learning and Learning Disabilities", 2 (1).

Candelier M. (2008), Approches plurielles, didactique du plurilinguisme: le même et l'autre. "Cahiers de l'ACEDLE", volume 5.

CARAP Cadre de Référence pour les Approches Plurielles des Langues et des Cultures. (2007). Graz: Conseil de l'Europe. Also available at: http://carap.ecml.at/Portals/11/documents/C4pub2007F_20080228_FINAL.pdf Accessed 10.08.2016.

Chomentowski M. (2009). L'échec scolaire des enfants de migrants: l'illusion de l'égalité. Paris, L'Harmattan.

Coste D. (2002), Actualité de la réflexion sur le curriculum. L'École Valdôtaine.

Coste D., Moore D., Zarate G. (2009). Competence plurilingue et pluriculturelle. Strasbourg: Division des Politiques linguistiques. Also available at:_https://www.coe.int/t/dg4/linguistic/Source/ SourcePublications/CompetencePlurilingue09web_FR.pdf Accessed 10.08.2016.

Douillard C., Vinérier A., Carré C. (2011), Savoirs, savoir-faire, savoir-être... Regards de recruteurs de formateurs / dans Bretegnier, Aude (dir.), Formation linguistique en contextes d'insertion. Compétences professionnelles, posture, professionnalité: concevoir un cadre de référence(s), Collection «Transversales», 28. Bern, Peter Lang.

Europos Tarybos rekomendacija dè 2016 m. Lietuvos nacionalinès reformu programos su Tarybos nuomone dèl 2016 m. Lietuvos stabilumo programos (2016-05-18). COM(2016) 335 final. Briuselis: 4.

Gohard-Radenkovic A., Jakavonyte-Staškuviene D., Skakova A. (2015), L'éducation plurilingue et les «approches plurielles» au service de quoi et au profit de qui? Histoire d'un désenchantement. In: Adami H. et Andre V. (dir.), De l'idéologie monolingue à la doxa plurilingue: regards pluridisciplinaires, Transversales. Bern, Peter Lang.

Mazunya M., Djihouessi B.C. (2014), Aspects didactiques du bi-plurilinguisme./ Approches didactiques du bi-plurilinguisme en Afrique: Apprendre en langues nationales et en français pour réussir à l'école. Paris: Editions des archives contemporaines.

Maurer B. (2014), L'éveil aux langues. / Approches didactiques du bi-plurilinguisme en Afrique: Apprendre en langues nationales et en français pour réussir à l'école. Paris, Editions des archives contemporaines.

Paris S.G., Winograd P. (1990), How Metacognition Can Promote Academic Learning and Instruction. In: J.B. Fly, I. Lorna (Eds.), Dimensions of Thinking and Cognitive Instructions. Hillsdale, NJ, Lawrence Erlbaum Associates, Inc.

Prudent L.-F. (1981), Diglossie et interlecte. "Langages”, 61. Larousse, GRECO, CNRS, Université de Rouen.

Sagnier Ch. (2013), Métacognition et interactions en didactique des langues: perspectives sociocognitives. Berlin, Peter Lang.

Shankland R. (2013), Pédagogies nouvelles et changement sociétal / dans Rohart, Jean-Daniel. Renouveler l'éducation. Ressources pour des enjeux anthropologiques nouveaux. France, La Chronique Sociale.

Stalder P. (2010), Pratiques imaginées et images des pratiques plurilingues. Stratégies de communication dans les réunions en milieu professionnel international. Berne, Peter Lang. 
Stalder P. (2013), Management international: développer les compétences en innovant les formations ». In X. Yang \& L. Zheng, Culture et management. Paris, L'Harmattan.

Tarpinian A. (2013), Politique et école la dimension anthropologique / dans Rohart, Jean-Daniel. Renouveler l'éducation. Ressources pour des enjeux anthropologiques nouveaux. France: La Chronique Sociale, 2013.

Tarptautinio IV klasès mokiniu skaitymo gebejimu tyrimo PIRLS (Progress in International Reading Literacy Study) ataskaita 2011. (2012). Vilnius: Nacionalinis egzaminų centras. Also available at: http://www.egzaminai.lt/failai/3969_PIRLS2011_ATASKAITA.pdf Accessed 10.08.2016.

Tarptautinio skaitymo gebejimu tyrimo PIRLS (Progress in International Reading Literacy Study) ataskaita 2006. (2007), Vilnius: Nacionalinis egzaminų centras. Also available at: http://www. nec.lt/failai/263_tyrimai_pirls_pub_2006_skait_geb_ataskaita.pdf Accessed 10.08.2016.

Tarptautinis penkiolikmečiu tyrimas OECD PISA 2012. Ataskaita. Vilnius: Nacionalinis egzaminų centras, 2013. Also available at:

http://www.nec.lt/failai/3952_OECDPISA2012_ataskaita.pdf Accessed 10.08.2016.

Valstybinè švietimo 2013-2022 m. strategija. (2013), Valstybés žinios, Nr. 140-7095.

Vinérier A., «La formation des adultes en situation d'illettrisme: vers une pédagogie de la conscientisation». In: A. Bretegnier (Ed.), Op. Cit., 2007.

Vygotsky Lev Semyonovich (1978), Mind in Society: the Development of Higher Psychological Processes. Cambridge, MA, Harward University Press. 